Lina Perekhoda, Doctor of Pharmacy, Professor, Head of the Department, Head of department of Medicinal Chemistry, National University of Pharmacy, Pushkinska str., 53, Kharkiv, Ukraine, 61002

Sych Igor, Postgraduate Student, Department of Medicinal Chemistry, National University of Pharmacy, Pushkinska str., 53, Kharkiv, Ukraine, 61002

Sych Irina, PhD, Associate Professor, Department of Medicinal Chemistry, National University of Pharmacy, Pushkinska str., 53, Kharkiv, Ukraine, 61002

Bevz Natalia, PhD, Associate Professor, Department of Pharmaceutical Chemistry, National University of Pharmacy, Pushkinska str., 53, Kharkiv, Ukraine, 61002

Rakhimova Maryna, Assistant, Department of Medicinal Chemistry, National University of Pharmacy, Pushkinska str., 53, Kharkiv, Ukraine, 61002

Yaremenko Vitaliy, PhD, Associate Professor, Department of Medicinal Chemistry, National University of Pharmacy, Pushkinska str., 53, Kharkiv, Ukraine, 61002

УДК: 582.711:57.063:615.2

DOI: 10.15587/2519-4852.2018.153199

\title{
SEARCH OF THE PROMISING SPECIES OF SUBFAMILY AMYGDALOIDEAE AND PYROIDEAE USING THE CHEMOTAXONOMY
}

\author{
(C) N. Sydora, A. Kovaleva, O. Goncharov
}

Світова флора нараховує понад 1000 видів роду Crataegus L., до підроду Prunиs L. належать понад 30 видів, рід Malus Mill. містить 100 видів, до nidpidy Cerasus Juss. відноситься понад 150 видів. Незважаючи на різноманіття видів та достатню сировинну базу, лише деяки представники циих родів достатньо досліджені та знайшли своє використання як джерела біологічно активних речовин (БАР).

Мета. Провести хемотаксономічне дослідження представників родів Crataegus L., Prunus L., Malus Mill., Cerasus Juss.; встановити перспективні джерела БАР для одержання лікарських засобів.

Методи дослідження. Хемотаксономічне дослідження проводили з використанням методу графаналізу. Хемомаркерами служили фенольні сполуки та терпеноїди, ідентифіковані у генеративних та вегетативних органах представників родів Crataegus L., Prunus L., Malus Mill., Cerasus Juss. Iдентифiкацію терпеноїдів та органічних кислот проводили хромато-мас-спектрометричним методом на хроматографi Agilent Technology 6890N з мас-спектрометричним детектором 5973N. Флавоноїди та гідроксикоричні кислоти визначали хроматографічно.

Результати дослідження. Встановлені хімічні профілі вегетативних та генеративних органів 34 видів роду Crataegus L., 5 видів роду Prunиs L., 7 видів роду Malus Mill., 4 видів роду Cerasus Juss. Bстановлені перспективні види глоду, які містять основну групу БАР роду.

Висновки. За результатами хемотаксономічного дослідженя представників підродів Amygdaloideae ma Pуroideaе встановлені перспективні джерела біологічно активних речовин (БАР) видів родів Crataegus L., Prunus L., Malus Mill. ma Cerasus Juss. Встановлено, щзо хімічний профіль досліджених родів формують флавоноїди, терпеноїди та ароматичні кислоти. Перспективні види глоду були введені до складу фітокомплексу «Кратофіт»

Ключові слова: розоцвіті, глід, яблуня, вишня, слива, листя, квітки, плоди, таксон, хемотаксономія

\section{Introduction}

The representatives of genus Crataegus L., Malus Mill., Prunus L. and Cerasus Juss. belong to the family Rosaceae L. (Rose) subfamily Amygdaloideae and Pyroideae. According to modern data Cerasus Juss. and Prunus L. belong to the Amygdaeae, genus Crataegus L. and Malus Mill. - Pyreae [1].

In the world of flora, the genus Crataegus L. has more than 1000 species, the Prunus L. - more than 30 species, the Malus Mill. - more than 100 species, the Cerasus Juss. - more than 150 species.
2. Formulation of the problem in a general way, the relevance of the theme and its connection with important scientific and practical issues

Despite the wide species composition, only some representatives of the genera Crataegus L., Prunus L., Malus Mill. and Cerasus Juss. thoroughly investigated. Most of the existing species are not sufficiently studied. The feature of the above genus is that their representatives are easily hybridize as within the genus and between families, which complicates their identification [2]. Because of this, the taxonomy of the 
family and the genus is a subject of constant review and needs to be clarified.

\section{Analysis of recent studies and publications in} which a solution of the problem are described and to which the author refers

According to the characters of the morphological structure of generative and vegetative organs, modern systematics are point 25 botanical sections of the genus Crataegus L. the main of which are: Henryanae Sarg., Pinnatifida Zbl., Sanguineae Zbl., Douglasii Loud., Pentagynae Zbl., Azaroli Loud., Oxyacanthae Zbl., Molles Sarg., Tenuifoliae Sarg., Rotundifoliae Eggl., Virides Sarg., Crus-Galli Loud., Punctatae Loud., Parvifoliae Loud., Flavae Loud., Macracantae Loud., Dilatatae Sarg. 8 other sections are endemic species.

A chemotaxonomic study of the genus Crataegus L. using phenolic compounds of 12 species was previously carried out. As a result, it was found that for all investigated species the presence of hyperoside, quercetin and chlorogenic acid [3].

Modern systematics are separated Malus Mill. as an independent genus, although earlier it was a sub-genus of the genus Pyrus L. By the features of the morphological structure the genus Malus Mill. is divided into 2 sections: Pumilae Rehder. - M. silvestris Mill., $M$. domestica Borkh. Handb., M. prunifolia. (Willd.) Borkh., M. orientalis Ugl. = M. pumila Grossh.), M. Sieversii (Ldb.) M. Roem, M. Niedzwetzkyana Diek., M. prunifolia (Willd.) Borkh.) and Baccatae Render - M. baccata (L.) Borkh. Handb., M. Pallasiana Juz., M. sachalinensis Juz., M. manshurica (Maxim.) Kom. [4]. The most studied are species of sections of Pumilae Rehder. Representatives of the Baccatae Render. section have practically not been studied from a pharmacological point of view.

In Ukrainian flora two wild species are described - M. silvestris Mill. and M. praecox (Pall.) Borkh., and also 4 cultivated species $-M$. domestica Borkh., $M$. baccata (L.) Borkh., M. prunifolia (Willd.) Borkh. and M. sachalinensis Juz.

The genus Cerasus Juss. is consist of subgenus Typocerasus Koehne ex Kurt and Microcerasus Webb. To subgenus Typocerasus are belong sections:

1. Mahaleb Koehne - C. Maximowiczii (Rupr.) Kom., C. mahaleb (L.) Mill.;

2. Pseudocerasus Koehne-C. sachalinensis Kom.;

3. Hypadenium Koehne - C. glandulifolia (Rupr. Et Maxim.) Kom., C. avium (L.) Moench., C. fruticosa (Pall.) G. Woron., C. austera (L.) Roem. та C. colina Lej. et Court. In modern genus system is devided a section Eucerasus Koehne., which include C. avium (L.) Moench., C. fruticosa (Pall.) G. Woron. and C. vulgaris Mill. [5].

The representatives subgenus Microcerasus divided into 2 sections:

1. Spiraeopsis Koehne - C. glandulosa (Thunb.) Lois.;

2. Amygdalocerasus Koehne ex Kurt. - C. microcarpa (C.A.M.) Boiss., C. araxina Poyark., C. incana (Pall.) Spach., C. pseudoprostrata Poyark., C. erythrocarpa Newski., C. verrucosa Newski., C. Jacquemontii (Hook.) Buser., C. alaica Poyark., C. tianschanica Poyark. and C. turcomanica Poyark.
In Ukrainian flora 6 species of Prunus Mill. genus are described - P. spinosa L., P. stepposa Kotov., $P$. moldavica Kotov., P. domestica L., P. divaricata Ldb., $P$. insitilia $\mathrm{L}$. The most widespread in Ukraine of species the genus Prunus Mill. are: P. domestica L.; P. spinosa L.; $P$. salicina L.; $P$. cerasifera Ehrh.; $P$. americana Marsh.; P. ussuriensis K. et K.; P. nigra Ait; P. angustifolia Marsh.; P. hortulana Bail.; P. munsoniana W. and Hed.; P. Simonii Car. [6].

\section{The field of research considering the general problem, which is described in the article}

After analyzing the current state of research of representatives of the genus Crataegus L., Prunus L., Malus Mill. and Cerasus Juss., it can be concluded, that among species of the genus Crataegus L. 14 species have been studied, in genus Prunus L., Malus Mill. and Cerasus Juss. are sufficiently studied BAS of the species Prunus domestica, Prunus spinosa, Malus domestica, Malus silvestris, Cerasus vulgaris, Cerasus avium and their varieties. Other species of these genus were practically not investigated. We believe that the scientific interest is conducting a chemotaxonomic study of representatives of this subgenus to clarify their position in the genus system and to search for new sources of BAS, as well as to obtain substances for the creation of phytopreparations.

\section{Formulation of goals (tasks) of article}

To conduct a comparative chemo-taxonomic study of the genus Crataegus L., Prunus L., Malus Mill. and Cerasus Juss., to establish the chemical profiles of the genera, to establish promising for medicine species.

6. Presentation of the main research material (methods and objects) with the justification of the results

The objects of chemotaxanomic study were vegetative and generative organs of 34 species of genus $\mathrm{Cra}$ taegus L.: C. pinnatifida Bge. (C. pinnatifida var. psilosa C. K. Schneid.), C. Maximowiczii C.K. Schneid (C. altaica var. villosa Lge.), C. chlorosarca Maxim. (C. atrocarpa E. Wolf), C. schneideri C.K. Schneid., C. kansuensis Wils., C. almaatensis Pojark., C.pseudomelanocarpa M. Pop., C.laevigata Loud., C. oxyacantha L. (C. oxyacanta var. genuina Rouy et Camus), C. ambiguae C. A. M. (C. pseudoambiqua A. Pojark.), C. kyrtostyla Fingerh., C. pseudokyrtostyla Klok., C. subrotunda Klokk., C. curvisepala Lindm., $C$. fallacina Klok., C. turkestanica A. Pojark., C. monogyna Jacq. (C.monogyna va. intermedia (Schur) Jav.), C. canadensis Sarg., C. submollis Sarg., C. arnoldii Sarg., C.densiflora Sarg., C. festiva Sarg., C. flabellata (Bosc) C.Koch, C. rotundifolia Moench., C. punctata Jacq., C.rivularis Nutt., C. douglasii Lindl., C. prunifolia (Poir.) Pers., C. macracantha Lodd., C. pringlei Sarg., $C$. holmesiana Ashe., C. pedicelata Sarg., C. coccinoides Asche., C. cuneata S. et Z.; 4 species of genus Cerasus Juss.: C.avium L., C. fruticosa Pall., C. vulgaris Mill., C. glandulosa (Thunb.) Lois.; 7 species of genus Malus Mill.: M. silvestris, M. domestica Borkh. Handb., $M$. prunifolia (Willd.) Borkh., M. baccata (L.) Borkh. Handb., M. manshurica (Maxim.) Kom., M. cerasifera, 
M. coronaria; 5 species of genus Prunus L.: Pr. domestica L., Pr. spinosa L., Pr. salicina Lindl., Pr. divaricata Ldb., Pr. americana.

The research was carried out using the taxonomic analysis [7]. As chemo-markers used flavonoids, terpenoids, aromatic acids. Flavonoids and hydroxycinnamic acids identified chromatographically in a solvent system $n$ - butanol - acetic acid - water (10: 2: 3 ) and $2 \%$ solution of acetic acid [8]. Alcohol extracts of the studied species were chromatographed [9]. The results were evaluated by chromatography colored spots substances in daylight and UV- light before and after processing the chromatogram a chromogenic reagents (pair of ammonia, $10 \%$ alcohol solution of sodium hydroxide) [10].

Terpenoids and aromatic acids in the raw material were determined by chromatographic mass spectrometry on a Agilent Technology 6890N chromatograph with a $5973 \mathrm{~N}$ mass spectrometry detector [11]. Substances from the raw material were extracted with hexane. The content of the compounds was calculated relative to the internal standard $(50 \mu \mathrm{g}$ solution of tridecane in hexane). The identification of the compounds used data from the NIST05 and WILEY 2007 mass spectrum libraries with a total number of spectra of over 470000 in combination with programs for identifying AMDIS and NIST [12].

The compounds were determined in each species and added in the matrix table, after which for each species at the boundary of the genus, the coefficients of the pair affinity (Cpa) and the coefficient of group affinity (Cga) were determined on the basis of the chemical characteristics of the generative and vegetative organs.

In study a generative organs genus Crataegus L. was analyzed 4760 stages signs, genus Malus Mill. 441, genus Cerasus Juss. - 212, genus Prunus L. - 414.
In study vegetative organs - genus Crataegus L. 4760 stages of signs, genus Malus Mill. - 553, genus Cerasus Juss. - 252, genus Prunus L. - 384.

As a result of the study, chemical profiles of vegetative and generative organs of the genera were established. It should be noted that for identifying the characteristic compounds of genera were selected a chemical characteristics for which Cpa was from $75 \%$ to $100 \%$.

For a generative organs the species of Crataegus L. general are compounds: terpenoids (eugenol, cislinalool oxyde, trans-linalool oxyde, $\beta$-phenylethyl alcohol, squalen), flavonoids (quercetin, bioquercetin, hyperoside, rutin), organic acids ( $p$-hydroxybenzoic acid, benzoic, phenylacetic, salicylic, 4-hydroxycinnamic, vanillinic, chlorogenic, coffeic, pherulic, neochlorogenic, gentisinic, lilac) [13].

The chemical profile of vegetative organs of hawthorn species is characterized by terpenoids and aldehydes (benzaldehyde, cis-linalool oxyde, trans -2hexenal, eugenol, squalen, nerol), flavonoids (quercetin), aromatic acids ( $p$-coumaric, benzoic, phenylacetic, salicylic, vanillinic, chlorogenic, coffeic, pherulic, neochlorogenic, gentisinic, lilac) [14]. The taxons, which have the highest values of Cga are characterize the hawthorn by the chemical composition of the vegetative and generative organs and form a chemical profile of the genus. The main group of species of the genus Crataegus, having largest information weight according the chemical composition of generative organs, represented by 10 taxons: C. prunifolia $(\mathrm{Cga}-1523 \%)$, C. douglasii (Cga - $1486 \%)$, C. cuneata (Cga $1485 \%)$, C. pseudokyrtostylla (Cga - $1463 \%), C$. almaatensis (Cga - $1457 \%)$, C. chlorosarca (Cga $1437 \%)$, C. ambiquae (Cga - $1437 \%)$, C. rotundifolia (Cga-1426\%), C. flabellata (Cga-1363\%), C. densiflora $(\mathrm{Cga}-1320 \%)$ (Table 1).

Table 1

Cpa the main grous of taxons according chemical content of generative organs

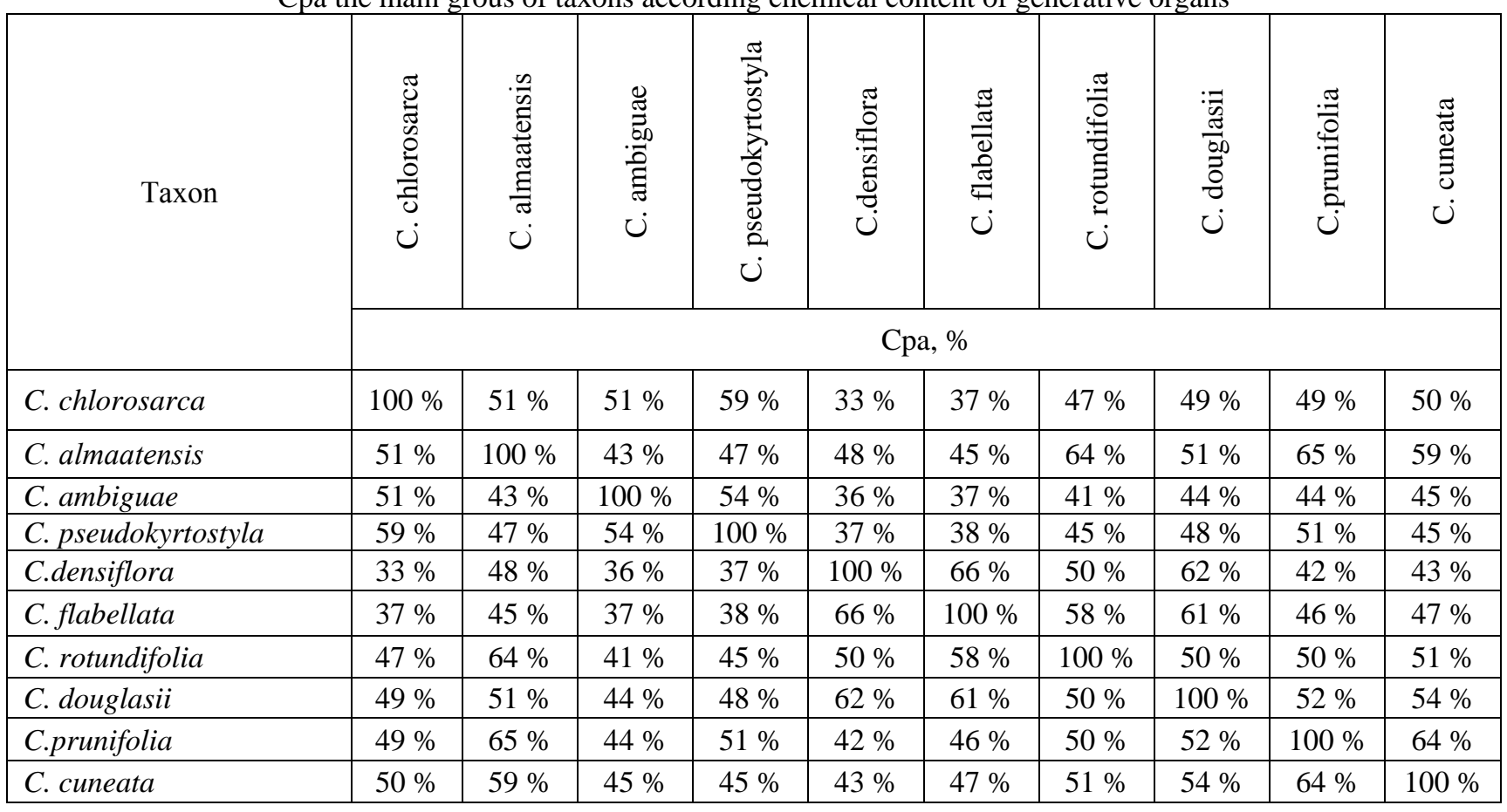


The main group of species of genus Crataegus L. according vegetative characteristics include 14 taxons: C. oxyacantha (Cga - $1416 \%)$, C. chlorosarca (Cga $1411 \%)$, C. almaatensis (Cga - $1411 \%)$, C. festiva (Cga - $1380 \%)$, C. pseudokyrtostyla (Cga - $1371 \%)$, C. subrotunda (Cga - $1368 \%)$, C.prunifolia (Cga $1366 \%)$, C.pseudomelanocarpa (Cga - $1354 \%$ ), C. submollis (Cga - $1354 \%)$, C. punctata (Cga - 1351\%), C. curvisepala (Cga - $1348 \%)$, C. pinnatifida (Cga $1339 \%)$, C.laevigata (Cga-1323\%), C. cuneata (Cga$1311 \%$ ) (Table 2).

The main group of taxons that characterize the genus Crataegus L. by the chemical composition of generative and vegetative organs include $C$. prunifolia (Cpa - $1449 \%)$, C. chlorosarca (Cga - $1424 \%)$, C. almaatensis (Cga - $1434 \%)$, C. pseudokyrtostylla (Cga - $1417 \%)$, C. cuneata (Cga - $1396 \%)$, C. subrotunda $(\mathrm{Cga}-1374 \%)$.

After analyzing the chemical composition of generative and vegetative organs of the genus Crataegus L., the basic chemical compounds that form the chemoprofile of the genus are established: cis-linalool oxyde, linalool, squalen, quercetin, hyperoside, rutin, $p$ hydroxybenzoic acid, chlorogenic acid, pherulic acid, vanillinic acid, lilac acid.

Table 2

Cpa the main grous of taxons according chemical content of vegetative organs

\begin{tabular}{|c|c|c|c|c|c|c|c|c|c|c|c|c|c|c|}
\hline \multirow[t]{2}{*}{ Taxon } & 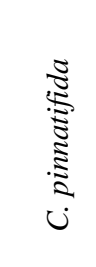 & 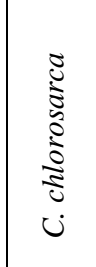 & 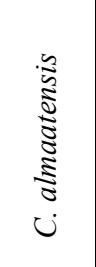 & 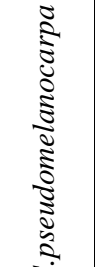 & 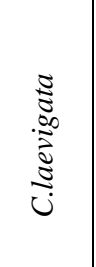 & 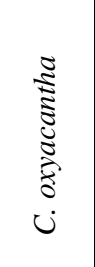 & 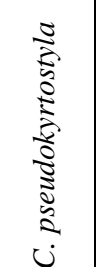 & 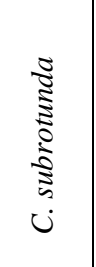 & 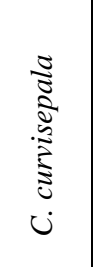 & 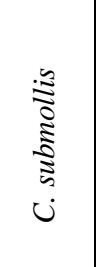 &  & 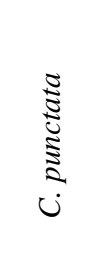 & 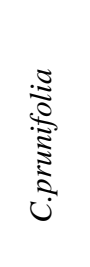 & 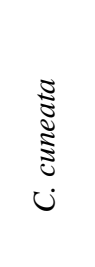 \\
\hline & \multicolumn{14}{|c|}{ Сра, \% } \\
\hline C. pinnatifida & $100 \%$ & $47 \%$ & $44 \%$ & $42 \%$ & $45 \%$ & $43 \%$ & $37 \%$ & $40 \%$ & $41 \%$ & $40 \%$ & $39 \%$ & $48 \%$ & $51 \%$ & $45 \%$ \\
\hline C. chlorosarca & $47 \%$ & $100 \%$ & $71 \%$ & $72 \%$ & $38 \%$ & $72 \%$ & $77 \%$ & $80 \%$ & $68 \%$ & $71 \%$ & $73 \%$ & $41 \%$ & $41 \%$ & $38 \%$ \\
\hline C. almaatensis & $44 \%$ & $71 \%$ & $100 \%$ & $65 \%$ & $37 \%$ & $65 \%$ & $70 \%$ & $68 \%$ & $68 \%$ & $65 \%$ & $66 \%$ & $43 \%$ & $40 \%$ & $37 \%$ \\
\hline $\begin{array}{l}\text { C.pseudomelan } \\
\text { ocarpa }\end{array}$ & $42 \%$ & $72 \%$ & $65 \%$ & $100 \%$ & $38 \%$ & $64 \%$ & $73 \%$ & $76 \%$ & $60 \%$ & $61 \%$ & $74 \%$ & $40 \%$ & $41 \%$ & $38 \%$ \\
\hline C.laevigata & $45 \%$ & $38 \%$ & $37 \%$ & $38 \%$ & $100 \%$ & $36 \%$ & $39 \%$ & $38 \%$ & $33 \%$ & $32 \%$ & $41 \%$ & $71 \%$ & $82 \%$ & $82 \%$ \\
\hline C. oxyacantha & $43 \%$ & $72 \%$ & $65 \%$ & $64 \%$ & $36 \%$ & $100 \%$ & $73 \%$ & $64 \%$ & $73 \%$ & $74 \%$ & $69 \%$ & $39 \%$ & $39 \%$ & $36 \%$ \\
\hline $\begin{array}{l}\text { C. } \\
\text { pseudokyrtostyla }\end{array}$ & $37 \%$ & $77 \%$ & $70 \%$ & $73 \%$ & $39 \%$ & $73 \%$ & $100 \%$ & $81 \%$ & $69 \%$ & $68 \%$ & $79 \%$ & $40 \%$ & $42 \%$ & $39 \%$ \\
\hline C. subrotunda & $40 \%$ & $80 \%$ & $68 \%$ & $76 \%$ & $38 \%$ & $64 \%$ & $81 \%$ & $100 \%$ & $63 \%$ & $68 \%$ & $77 \%$ & $40 \%$ & $41 \%$ & $38 \%$ \\
\hline C. curvisepala & $41 \%$ & $68 \%$ & $68 \%$ & $60 \%$ & $33 \%$ & $73 \%$ & $69 \%$ & $63 \%$ & $100 \%$ & $72 \%$ & $61 \%$ & $42 \%$ & $36 \%$ & $33 \%$ \\
\hline C. submollis & $40 \%$ & $71 \%$ & $65 \%$ & $61 \%$ & $32 \%$ & $74 \%$ & $68 \%$ & $68 \%$ & $72 \%$ & $100 \%$ & $64 \%$ & $40 \%$ & $35 \%$ & $32 \%$ \\
\hline C. festiva & $39 \%$ & $73 \%$ & $66 \%$ & $74 \%$ & $41 \%$ & $69 \%$ & $79 \%$ & $77 \%$ & $61 \%$ & $64 \%$ & $100 \%$ & $43 \%$ & $45 \%$ & $41 \%$ \\
\hline C. punctata & $48 \%$ & $41 \%$ & $43 \%$ & $40 \%$ & $71 \%$ & $39 \%$ & $40 \%$ & $40 \%$ & $42 \%$ & $40 \%$ & $43 \%$ & $100 \%$ & $77 \%$ & $73 \%$ \\
\hline C.prunifolia & $51 \%$ & $41 \%$ & $40 \%$ & $41 \%$ & $82 \%$ & $39 \%$ & $42 \%$ & $41 \%$ & $36 \%$ & $35 \%$ & $45 \%$ & $77 \%$ & $100 \%$ & $89 \%$ \\
\hline C. cuneata & $45 \%$ & $38 \%$ & $37 \%$ & $38 \%$ & $82 \%$ & $36 \%$ & $39 \%$ & $38 \%$ & $33 \%$ & $32 \%$ & $41 \%$ & $73 \%$ & $89 \%$ & $100 \%$ \\
\hline
\end{tabular}

The chemical profile the generative organs of genus Malus Mill. are forming $\alpha$-terpineol, geraniol, eugenol, aromatic acids (benzoic, phenylacetic, salicylic, vanillinic, lilac, chlorogenic, pherulic), flavonoids (hyperoside and rutin). For vegetative organs common compounds are cis-bisabolene epoxide, $\alpha$-pharnezene, linalool, damascenon, limonen, squalen, organic acids (fumaric, phenylacetic, vanillinic, $p$-oxybenzoic, pherulic, $p$-coumaric, chlorogenic), rutin, naringenin, epicatechin.

For generative organs of the genus Cerasus Juss. the most characteristic BAS are: trans-linalool oxyde, linalool, lilac aldehyde, terpen-4-ol, $\alpha$-terpineol, nerol, geraniol, damascenon, squalen, aromatic acids (benzoic, salicylic), rutin. In vegetative organs established nonanale, $\alpha$-terpineol, trans-linalool oxide, cis-linalool oxyde, 4-vinile-2-methoxyphenol, damascenon, ionone-5,6- epoxide, squalen, hexacosane, aromatic acids (benzoic, p-coumaric, $p$-hydroxybenzoic, chlorogenic), flavonoids luteolin, vitexin, naringenin, gerniarin, catechin [15].

The chemical profile of generative organs of the genus Prunus L. is represented by nerol, limonene, squalene, quercetin, hyperoside and rutine. For vegetative organs, the most characteristic are squalene, chlorogenic acid, isoqueretine, quercetin, avicularine, rutine [16].

Practically in all investigated objects are identified fumaric, oxalic, malonic, levulinic, succinic, malic, ascorbic, citric acids.

7. Conclusions from the conducted research and prospects for further development of this field

The chemotaxonomic study of the genera Crataegus L., Malus Mill., Cerasus Juss., Prunus L. 
was carried out and promising species were identified as a sources of BAS. According to the chemical composition of generative and vegetative organs the $\mathrm{Cpa}$ and $\mathrm{Cga}$ are determined. Established chemical profiles of vegetative and generative organs of the genera, as well as the main groups of taxons. The promising hawthorn species was edded to complex «Kratophyt».

\section{References}

1. Origins and Evolution of Subfam. Maloideae (Rosaceae) / Phipps J. B. et. al. // Systematic Botany. 1991. Vol. 16, Issue 2. P. 303-332. doi: http://doi.org/10.2307/2419283

2. Talent N., Dickinson T. A. Polyploidy in Crataegus and Mespilus (Rosaceae, Maloideae): evolutionary inferences from flow cytometry of nuclear DNA amounts // Canadian Journal of Botany. 2005. Vol. 83, Issue 10. P. 1268-1304. doi: http://doi.org/10.1139/b05-088

3. Goncharov N. F., Kovaleva A. M., Komissarenko A. N. Fenol'nye soedineniya severoamerikanskikh vidov roda boyaryshnik // Rossiyskiy mediko-biologicheskiy vestnik imeni akademika Pavlova. 2008. Issue 3. P. 150-154.

4. Kamelin R. V. Rozotsvetnye (Rosaceae). Bornaul, 2006. 100 p.

5. Phylogeny and classification of Rosaceae / Potter D. et. al. // Plant Systematics and Evolution. 2007. Vol. 266, Issue 1-2. P. 5-43. doi: http://doi.org/10.1007/s00606-007-0539-9

6. Eremin G. V. Genofond roda Prunus L. // Trudy po prikladnoy botanike, genetike i selektsii. 2017. Vol. 164. P. $208-217$.

7. Sydora N. Morphological and taxonomic study of oxyacanthae Zbl. section of crataegus L. genus by vegetative characteristics // ScienceRise: Pharmaceutical Science. 2018. Vol. 1, Issue 11. P. 36-41. doi: http://doi.org/10.15587/25194852.2018.124432

8. A study of the chemical constituents of the leaves of Crataegus pinnatifida / Chen J. et. al. // Asian Journal of Traditional Medicines. 2008. Vol. 3. P. 80-83.

9. Hamahameen B. A., Jamal B. Determination of Flavonoids in the Leaves of Hawthorn (Crataegus Azarolus ) of Iraqi Kurdistan Region by HPLCAnalysis // International Journal of Bioscience, Biochemistry and Bioinformatics. 2013. Vol. 3, Issue 1. P. 67-70. doi: http://doi.org/10.7763/ijbbb.2013.v3.166

10. Lenchyk L. V., Upyr D. V., Ovezgeldiyev D. Phytochemical investigation of bird cherry fruits // Der Pharmacia Lettre. 2016. Vol. 8 (6). P. 73-76.

11. Sydora N., Kovalova A., Komissarenko A. Gas chromatographic-mass spectrometric studies of organic acids of Crataegus pedicelata Sarg leaves // Science and Education Studies. 2016. Vol. 2, Issue 1 (17). P. 769-774. P. 195-207.

12. Methods of the chromate-mass-spectrometric research / Bicchi C. et. al. // Journal of Chromatography A. 2016. Issue 1-2.

13. GC/MS study of essential oil components from flowers of Crataegus jackii, C. robesoniana, and C. flabellate / Kovaleva A. M. et. al. // Chemistry of Natural Compounds. 2009. Vol. 45, Issue 4. P. 582-584. doi: http://doi.org/10.1007/s10600-009-9373-3

14. Sydora N. V., Kovalova A. M. Gas chromatographic-mass spectrometric studies the volatile compounds and organic acids the leaves of Crataegus macracantha Loud // American Journal of Science and Technologies. 2016. Vol. 3, Issue 1 (21). P. 1041-1045.

15. Lenchyk L., Shapoval O., Kyslychenko V. Phytochemical study and determination of pharmacological activities of cherry shoots dry extract // ScienceRise: Pharmaceutical Science. 2016. Vol. 1, Issue 1. P. 40-45. doi: http://doi.org/10.15587/25194852.2016.72746

16. Lenchyk L. V. Determination of phenolic compounds in prunus domestica leaves extract // Scripta Scientifica Pharmaceutica. 2016. Vol. 2, Issue 2. P. 31-35. doi: http://doi.org/10.14748/ssp.v2i2.1302

Дата надходження рукопису 06.11.2018

Natalia Sydora, PhD, Associate Professor, Department of Pharmacognosy, National University of PharmacyPushkinska str., 53, Kharkiv, Ukraine, 61002

E-mail: sydora2005@gmail.com

Alla Kovaleva, Doctor of Pharmaceutical Sciences, Professor, Department of Pharmacognosy, National University of Pharmacy, Pushkinska str., 53, Kharkiv, Ukraine, 61002

E-mail: allapharm@yahoo.com

Alexandr Goncharov, PhD, assistant, Department of Pharmacognosy, National University of Pharmacy, Pushkinska str., 53, Kharkiv, Ukraine, 61002

E-mail: gnosy@nuph.edu.ua 